\title{
Perennial pastures for marginal farming country in southern Queensland. 2. Potential new grass cultivar evaluation
}

\author{
RICHARD G. SILCOCK ${ }^{1}$, CASS H. FINLAY ${ }^{2}$, DON S. LOCH ${ }^{3}$ AND GREG L. HARVEY ${ }^{4}$ \\ ${ }^{1}$ Queensland Department of Agriculture, Fisheries and Forestry, Dutton Park, Qld, Australia. www.daff.qld.gov.au \\ ${ }^{2}$ Formerly Queensland Department of Primary Industries, Toowoomba, Qld, Australia \\ ${ }^{3}$ Formerly Queensland Department of Primary Industries \& Fisheries, Gympie, Qld, Australia \\ ${ }^{4}$ Queensland Department of Agriculture, Fisheries and Forestry, Toowoomba, Qld, Australia
}

Keywords: Herbicide tolerance, persistence, forage yield, establishment ease, commercialization, seed production.

\begin{abstract}
Trials in the Condamine-Balonne basin, Australia, compared 11 promising perennial pasture grass accessions (4 Bothriochloa, 2 Cenchrus, 2 Urochloa and 1 each of Digitaria, Eragrostis and Panicum species) against the best similar commercial cultivars on the basis of ease of establishment from seed, persistence once established, forage yield and ease of seed production. Accessions sown at a site were determined by prior experience with them on a range of soils. High quality seed was relatively easy to produce for both Urochloa species and for Eragrostis curvula CPI 30374 but problematic for the Bothriochloa spp. Once established, all accessions persisted for 3-5 years and most were well grazed, but adequate establishment was sometimes a problem with Panicum stapfianum and Bothriochloa ewartiana. The dry matter yield ratings of the non-commercial lines were similar to those of the commercial equivalents of the same species. While agronomically valuable, none of the promising new grasses was considered worthy of commercialization at this point because their strengths did not warrant the setting up of a seed-production business in competition with current commercial enterprises. Long-standing cultivars such as Gayndah buffel and Nixon sabi grass continued to exhibit their superior pasture qualities.
\end{abstract}

\section{Resumen}

En una serie de ensayos en la cuenca de Condamine-Balonne, Queensland, Australia, se compararon 11 accesiones promisorias de especies de gramíneas perennes (4 accesiones del género Bothriochloa, 2 de Cenchrus, 2 de Urochloa y 1 cada una de los géneros Digitaria, Eragrostis y Panicum) vs. los mejores cultivares comerciales de éstas o especies similares. Se evaluaron la facilidad de establecimiento por semilla, la persistencia de plantas establecidas, la producción de forraje y la facilidad para producir semillas. Las accesiones utilizadas habían sido previamente seleccionadas en trabajos de campo en un amplio rango de suelos. Fue relativamente fácil producir semilla de alta calidad de ambas especies de Urochloa y de Eragrostis curvula CPI 30374, pero fue difícil para las especies de Bothriochloa. Una vez establecidas, todas las accesiones persistieron durante 3-5 años y en su mayoría mostraron buen consumo por animales en pastoreo. En Panicum stapfianum y B. ewartiana se observaron algunos problemas para el establecimiento. La producción de materia seca de las accesiones fue similar a la de sus equivalentes comerciales de la misma especie. No obstante algunas ventajas agronómicas, las nuevas gramíneas no mostraron ser lo suficientemente promisorias para continuar con el proceso de comercialización puesto que sus fortalezas aún no justifican un programa de producción de semillas en competencia con las empresas comerciales actuales. Gramíneas bien conocidas como cv. Gayndah del pasto búfel (Cenchrus ciliaris) y cv. Nixon del pasto sabi (Urochloa mosambicensis) confirmaron sus cualidades superiores.

Correspondence: R.G. Silcock, DAFF Animal Sciences, GPO Box 267, Brisbane, Qld 4001, Australia.

Email: richard.silcock@daff.qld.gov.au 


\section{Introduction}

In southern inland Queensland (26-29 S) perennial pasture species such as lucerne or alfalfa (Medicago sativa) and Rhodes grass (Chloris gayana) are well suited to the more fertile cracking clays and krasnozems, when annual rainfall is above $700 \mathrm{~mm}$, as are short-lived annual medics (Medicago spp.) and forage sorghums (Sorghum spp.) (Thompson 1988; Bellotti et al. 1991). In drier environments the number of suitable species diminishes; they become more soil-specific, and the time required in a pasture ley phase increases for adequate soil restoration. Buffel grass (Cenchrus ciliaris) is a common species sown on sandy soils, while Bambatsi panic (Panicum coloratum var. makarikariense cv. Bambatsi) grows well on heavy cracking clays. Lucerne (alfalfa) has a wide soil adaptation and remains important, where soil fertility is adequate and soil nematode problems are minimal. However, all 3 have deficiencies - the lifespan of lucerne pastures in this environment is short; Bambatsi panic can cause photosensitization in livestock; and buffel grass is hard to plow out from a ley pasture phase. In some places no common commercial cultivars are well adapted, e.g. on many hard-setting poplar box (Eucalyptus populnea) soils (Blacket 1992).

Since few perennial pasture species can be recommended for use in southern inland Queensland, there is the risk that a serious new pest or disease outbreak could decimate an existing cultivar, severely reducing available options. Hence research was needed to identify a wider range of possible cultivars than those currently available, namely buffel grass, lucerne, Premier digit grass (Digitaria eriantha ssp. smutsii cv. Premier) and creeping bluegrass (Bothriochloa insculpta) (Silcock et al. 2014). The emphasis was on soils other than cracking grey clays, for which a range of moderately successful cultivars exists. Soils of chief interest were those found beneath eucalypt woodlands rather than Acacia shrublands, but did not include cypress pine (Callitris glaucophylla) and spinifex (Triodia spp.) country, where the soils are too infertile, shallow or prone to serious erosion if cultivated.

This paper is the second of 2 that report on trials, where grass accessions, short-listed after earlier studies by Silcock et al. (2014), were compared against the best equivalent commercially available cultivars. It deals with the relative performance of these grasses and their potential for commercial release. The first paper assessed establishment success using a range of sowing techniques (Silcock and Finlay 2015).

\section{Methods}

A total of 17 perennial grass accessions (6 commercial and 11 experimental) were planted across 3 sites (Table 1). They were assessed for agronomic potential on 4 main features:

- Ease of establishment from seed,

- Persistence once established,

- Forage yield, and

- Ease of seed production (at specialist seed production facilities).

Only 8 accessions were evaluated at each site but Gayndah buffel (C. ciliaris cv. Gayndah) was always included as a reference standard. The soil characteristics of the sites and the sowing methods were described in Silcock and Finlay (2015). Briefly, the site near Yelarbon $\left(28.234^{\circ} \mathrm{S}, 150.721^{\circ} \mathrm{E}\right)$ was on a grey, sandy clay loam fringing brigalow (Acacia harpophylla) country, the one near Condamine $\left(26.797^{\circ} \mathrm{S}, 150.186^{\circ} \mathrm{E}\right)$ was on a brown, gritty, loamy-surfaced duplex soil, that was originally a poplar box/false sandalwood (Eremophila mitchellii) woodland, and the one near Roma $\left(26.795^{\circ} \mathrm{S}\right.$, $\left.148.766^{\circ} \mathrm{E}\right)$ was on a sandy red earth-surfaced duplex soil, that originally supported an open poplar box, belah (Casuarina cristata) and kurrajong (Brachychiton populneum) woodland.

\section{Seedling establishment}

Establishment methods consisted of 4 sowing times, 3 different seedbed preparations and 2 fertilizer levels $(0$ and $100 \mathrm{~kg} / \mathrm{ha}$ of Starterphos - 10\% N, 20\% P, 2\% S) (Silcock and Finlay 2015). Sowing occurred between spring and autumn from late 1992 to April 1994. Sowing dates were determined when adequate pre-sowing rain allowed the ground to be cultivated. Species were rated several times during the first year after each sowing for seedling density, weed competition and dry matter yield. Treatments were replicated 3 times and plot size varied from 25 to $200 \mathrm{~m}^{2}$ depending on the sowing event.

\section{Persistence and forage production}

Persistence was assessed in the 1994/95 summer and in 1998 and further observations continued, if the sites remained under pasture. Observers rated each plot for the density of plants of the sown accession, sown plant vigor, plot weediness, dry matter yield of the sown plant and apparent palatability to animals at the time. When no sown plants survived, the rating was zero. 
Table 1. List of the pasture accessions sown at the trial sites, their growth habit and seed characteristics and their original collection location. Homelands are listed in brackets where the lines used are from naturalized locations in Queensland.

\begin{tabular}{|c|c|c|c|c|c|}
\hline $\begin{array}{l}\text { Accession } \\
\text { code }\end{array}$ & Botanical name & Homeland & Status & Notes & $\begin{array}{l}\text { Sites } \\
\text { sown }^{1}\end{array}$ \\
\hline CPI 11408 & $\begin{array}{l}\text { Bothriochloa bladhii } \\
\text { var. glabra }\end{array}$ & Uncertain & $\begin{array}{l}\text { Now } \\
\text { cv. Swann }\end{array}$ & $\begin{array}{l}\text { Tufted; spring tillers prostrate; hairy } \\
\text { seed }\end{array}$ & $\mathrm{Y}, \mathrm{C}$ \\
\hline TN 47 & Bothriochloa ewartiana & St George, Qld & Native & Tufted; typical hairy Bothriochloa seed & $\mathrm{Y}$ \\
\hline CPI 52193 & Bothriochloa insculpta & Zambia & Experimental & Early-flowering; like cv. Bisset & $\mathrm{Y}$ \\
\hline CPI 69517 & Bothriochloa insculpta & Zimbabwe & Experimental & Like cv. Bisset but larger seedhead & $\mathrm{C}$ \\
\hline Bisset & $\begin{array}{l}\text { Bothriochloa insculpta } \\
\text { cv. Bisset }\end{array}$ & Kenya and Tanzania & Commercial & $\begin{array}{l}\text { Creeping; hairy nodes; elongated, hairy } \\
\text { seed }\end{array}$ & $\mathrm{Y}$ \\
\hline Medway & $\begin{array}{l}\text { Bothriochloa pertusa } \\
\text { cv. Medway }\end{array}$ & (Bogantungan, Qld) & Commercial & Creeping; hairless nodes; hairy seed & $\mathrm{C}, \mathrm{R}$ \\
\hline CPI 71914 & Cenchrus ciliaris & Somalia & Experimental & Like cv. Gayndah; very bristly fascicles & $\mathrm{R}$ \\
\hline CPI 73393 & Cenchrus ciliaris & $\begin{array}{l}\text { Limpopo Province, } \\
\text { Rep. South Africa }\end{array}$ & Experimental & $\begin{array}{l}\text { Like cv. Biloela; short, soft fascicle } \\
\text { bristles }\end{array}$ & $\mathrm{Y}, \mathrm{C}^{2}$ \\
\hline Gayndah & $\begin{array}{l}\text { Cenchrus ciliaris } \mathrm{cv} \text {. } \\
\text { Gayndah }\end{array}$ & Kenya / (Queensland) & Commercial & Tufted habit; bristly fascicles & $\mathrm{Y}, \mathrm{C}^{3}, \mathrm{R}$ \\
\hline Premier & $\begin{array}{l}\text { Digitaria eriantha } \mathrm{cv} . \\
\text { Premier }\end{array}$ & Rep. South Africa & Commercial & $\begin{array}{l}\text { Tufted; non-hairy leaves; elongated } \\
\text { seed with short hairs }\end{array}$ & $\mathrm{R}$ \\
\hline CPI 41192 & Digitaria milanjiana & Rep. South Africa & Experimental & $\begin{array}{l}\text { Creeping + tufts; very hairy leaves; seed } \\
\text { like cv. Premier }\end{array}$ & $\mathrm{R}$ \\
\hline CPI 30374 & Eragrostis curvula & Rep. South Africa & Experimental & $\begin{array}{l}\text { Tufted; hairy leaves; open seedhead; } \\
\text { tiny hairless seed }\end{array}$ & $\mathrm{R}$ \\
\hline Consol & $\begin{array}{l}\text { Eragrostis curvula var. } \\
\text { conferta cv. Consol }\end{array}$ & $\begin{array}{l}\text { Cape Province, Rep. } \\
\text { South Africa }\end{array}$ & Commercial & Tufted; compact seedhead; tiny seed & $\mathrm{R}$ \\
\hline CPI 73577 & Panicum stapfianum & Rep. South Africa & Experimental & $\begin{array}{l}\text { Tufted; open crown; smooth rounded } \\
\text { seed }\end{array}$ & $\mathrm{C}, \mathrm{R}$ \\
\hline Nixon & $\begin{array}{l}\text { Urochloa mosambicen- } \\
\text { sis cv. Nixon }\end{array}$ & Zimbabwe & Commercial & Open crown; large, flat hairy seed & $\mathrm{Y}, \mathrm{C}$ \\
\hline CPI 47122 & Urochloa oligotricha & Namibia & Experimental & Palatable; rounded, large, non-hairy seed & $\mathrm{Y}, \mathrm{C}$ \\
\hline CPI 60128 & Urochloa stolonifera & Rep. South Africa & Now cv. Saraji & Like a creeping cv. Nixon; hairy seed & $\mathrm{C}$ \\
\hline
\end{tabular}

${ }^{1} \mathrm{Y}=$ Yelarbon site, $\mathrm{C}=$ Condamine site, $\mathrm{R}=$ Roma site.

${ }^{2}$ only Sowing $4 . \quad{ }^{3}$ not in Sowing 4.

\section{Post-establishment management}

Grazing was controlled by a temporary fence during the establishment phase of each sowing and was used for short intervals to reduce weed competition and to enhance tillering of the young sown plants. After all sowings had established or failed due to drought (see Silcock and Finlay 2015), the fences were removed in late 1995. Thereafter the pastures were grazed when the owner's stock were in that paddock. The Yelarbon site became a cell in a time-controlled grazing system and, as such, was heavily grazed intermittently by cattle and often carried a large body of grass at other times. The Condamine site was in a small paddock and was heavily grazed by cattle at most subsequent visits, although never denuded. The Roma site was intermittently grazed in summer by sheep initially and cattle became the main grazing animals after 1998 .

\section{Seed production}

Seed of non-commercial lines was increased by specialist seed production units prior to these field sowings from irrigated, fertilized plants using sequential harvesting by hand and by machine. Herbicides were used to control weeds, and accessions were tested for sensitivity to those commonly used by the seed industry, following the protocols of Loch and Harvey (1993). Flowering 
times, pests and diseases, competitiveness and agronomic constraints were noted. A sample from most seed batches was sent for viability testing under international protocols.

\section{Statistical analysis}

GenStat 5.0 (GENSTAT 1987) and an in-house balanced factorial analysis package (BALF) were used for statistical testing of the data. The terms adopted for the final ANOVA model were Cultivation, Fertilizer, Grasses, Grasses x Cultivation and Fertilizer x Grasses, Data were checked for variance using 'residuals' plots and non-compliant sets were transformed prior to running the ANOVA again and doing LSD tests.

\section{Results}

\section{Seasonal conditions}

During establishment, rainfall was generally low (Silcock and Finlay 2015). Seasonal rain from first sowing until the year 2000 for the nearest official gauging station is shown in Table 2. During the persistence testing phase up to 2000, the Yelarbon site had excellent summers and autumns in 1995, 1996 and 1997 and an extremely wet winter in 1998. The Condamine site had good summers in 1996 and 1998 and an excellent winter in 1998. After the establishment year, the Roma site had fair to good rainfall throughout, including the wet 1998 winter, and a good spring in 2000 but had an extremely dry winter in 1997. In dry winters, heavier ground frosts than normal are experienced (Rainman 2003).

Since pre-sowing cultivation and fertilizer had minimal influence on establishment (Silcock and Finlay 2015), the results presented are the mean of the cultivation and fertilizer treatments.

\section{Early growth}

The field emergence of Urochloa species, Bothriochloa insculpta (creeping bluegrass) accessions and Medway pertusa (B. pertusa) was better than expected (Silcock and Finlay 2015). Conversely, B. bladhii and Panicum stapfianum had poorer field establishment than their seed tests foreshadowed. Thus denser seedling stands than expected arose from the Urochloa and the exotic Bothriochloa species, except for B. bladhii. Once established, all accessions persisted well for 3-5 years. Sparse stands of the tussock grasses B. bladhii and $P$. stapfianum remained sparse and dense stands of other lines competed well with local weeds. Stolons of the creeping bluegrasses readily grew up through large rolypoly bushes (Salsola kali and Sclerolaena muricata) and suppressed annual weeds well.

Table 2. Seasonal rainfall conditions $(\mathrm{mm})$ at the 3 trial sites between the first sowing and the year 2000 . Data are taken from Rainman (2003) using the nearest long-term recording station.

\begin{tabular}{|c|c|c|c|c|c|c|c|c|c|}
\hline Season & Long-term mean & 1993 & 1994 & 1995 & 1996 & 1997 & 1998 & 1999 & 2000 \\
\hline & \multicolumn{9}{|l|}{ Yelarbon } \\
\hline Summer $^{1}$ & 229 & 173 & 197 & 448 & 418 & 389 & 217 & 193 & 184 \\
\hline Autumn & 120 & 22 & 77 & 137 & 230 & 143 & 175 & 176 & 150 \\
\hline Winter & 100 & 68 & 31 & 52 & 66 & 21 & 367 & 97 & 40 \\
\hline \multirow[t]{2}{*}{ Spring } & 150 & 96 & 99 & 202 & 145 & 189 & 204 & 197 & 184 \\
\hline & \multicolumn{9}{|l|}{ Condamine } \\
\hline Summer & 260 & 138 & 263 & 283 & 421 & 289 & 405 & 215 & 262 \\
\hline Autumn & 137 & 16 & 199 & 47 & 199 & 101 & 178 & 103 & 67 \\
\hline Winter & 105 & 71 & 33 & 71 & 97 & 25 & 251 & 87 & 33 \\
\hline \multirow[t]{2}{*}{ Spring } & 151 & 98 & 140 & 237 & 170 & 195 & 204 & 123 & 132 \\
\hline & \multicolumn{9}{|l|}{ Roma } \\
\hline Summer & 228 & & 312 & 272 & 437 & 388 & 251 & 228 & 341 \\
\hline Autumn & 135 & & 162 & 47 & 168 & 109 & 163 & 196 & 128 \\
\hline Winter & 97 & & 30 & 47 & 81 & 6 & 187 & 91 & 63 \\
\hline Spring & 138 & 116 & 127 & 219 & 89 & 140 & 183 & 146 & 267 \\
\hline
\end{tabular}

${ }^{1}$ Summer $\quad=$ December of the previous year, January, February;

Autumn $\quad=$ March, April, May;

Winter = June, July, August; and

Spring $\quad=$ September, October, November. 


\section{Yield ratings and persistence}

Presentation dry matter yield ratings of the noncommercial lines were generally similar to the commercial equivalents (Tables 3, 4 and 5). Of the grasses sown at Yelarbon, Bisset (Bothriochloa insculpta) and B. insculpta 52193 were often very similar (Table 3). Urochloa oligotricha initially grew almost as well as the other Urochloa species and was more palatable, hence its lower yield rating later under grazing (Tables 3 and 4). However, it did not persist in the long term (to 2008), whereas Nixon (U. mosambicensis) did. By comparison, standing yields of B. insculpta generally increased over time relative to others.

Consol lovegrass (Eragrostis curvula) did not grow as well as E. curvula 30374 (Table 5) and Digitaria milanjiana generally outperformed Premier (D. eriantha). At Roma, Gayndah buffel (Cenchrus ciliaris) had a poor initial yield rating (Table 5) but that improved over time, as it did at Yelarbon. Yield rating of Medway pertusa (B. pertusa) increased steadily over time relative to almost all the other species at Roma (Table 5), but not at the Condamine site (Table 4).

Table 3. Dry matter yield ratings of sown grasses near Yelarbon on 3 occasions after the establishment phase. Ratings were on individual plots: the plot with the greatest yield (visually) of sown grass was given 10, those lacking sown grass assigned 0 , and a linear ranking applied for intermediate yields. Sowing 1 was on 10/12/92, Sowing 2 on 12/10/93, Sowing 3 on 17/12/93 and Sowing 4 on 13/4/94. LSD applies amongst accessions within an assessment date.

\begin{tabular}{|c|c|c|c|c|c|c|c|c|c|c|}
\hline \multirow{2}{*}{$\begin{array}{l}\text { Assessment } \\
\text { date }\end{array}$} & \multirow[t]{2}{*}{ Sowing } & \multicolumn{8}{|c|}{ Accession } & \multirow[b]{2}{*}{$\begin{array}{c}\text { LSD } \\
(\mathrm{P}<0.05)\end{array}$} \\
\hline & & $\begin{array}{c}C . \\
\text { ciliaris } \\
\text { Gayndah } \\
\end{array}$ & $\begin{array}{c}C . \\
\text { ciliaris } \\
73393 \\
\end{array}$ & $\begin{array}{c}U . \\
\text { mosambicensis } \\
\text { Nixon } \\
\end{array}$ & $\begin{array}{c}U . \\
\text { oligotricha }\end{array}$ & $\begin{array}{c}\text { B. } \\
\text { bladhii }\end{array}$ & $\begin{array}{c}B . \\
\text { ewartiana }\end{array}$ & $\begin{array}{c}\text { B. } \\
\text { insculpta } \\
\text { Bisset } \\
\end{array}$ & $\begin{array}{c}\text { B. } \\
\text { insculpta } \\
52193 \\
\end{array}$ & \\
\hline \multirow[t]{2}{*}{ 15/4/1994 } & 1 & 3.2 & 4.1 & 3.3 & 3.9 & 1.7 & 1.9 & 2.7 & 3.0 & 0.40 \\
\hline & 2 & 1.0 & 0.7 & 0.7 & 1.7 & 0.1 & 0.2 & 1.3 & 0.7 & 0.42 \\
\hline \multirow[t]{3}{*}{ 30/1/1995 } & 1 & 8.1 & 7.6 & 8.9 & 8.4 & 2.6 & 5.0 & 7.2 & 7.1 & 0.61 \\
\hline & 2 & 3.1 & 3.4 & 5.7 & 6.6 & 1.3 & 1.9 & 5.6 & 3.1 & 0.97 \\
\hline & 3 & 2.5 & 3.6 & 7.3 & 5.3 & 2.0 & 1.5 & 5.7 & 5.3 & 0.76 \\
\hline \multirow[t]{4}{*}{$29 / 5 / 1998$} & 1 & 8.4 & 6.7 & 7.4 & 5.3 & 3.1 & 4.7 & 8.4 & 7.2 & 1.12 \\
\hline & 2 & 3.9 & 3.3 & 6.7 & 3.8 & 1.6 & 2.4 & 7.3 & 5.2 & 0.88 \\
\hline & 3 & 4.2 & 4.7 & 8.0 & 4.0 & 4.9 & 4.0 & 8.8 & 8.4 & 1.17 \\
\hline & 4 & 3.6 & 1.9 & 3.0 & 1.8 & 1.9 & 1.2 & 5.5 & 7.2 & 0.87 \\
\hline
\end{tabular}

Table 4. Dry matter yield ratings of sown grasses near Condamine on 3 occasions after the establishment phase. Ratings were on individual plots with the plot with the greatest yield (visually) of sown grass given 10, those lacking sown grass assigned 0 , and a linear ranking applied for intermediate yields. Sowing 1 was on 22/12/92, Sowing 2 on 22/9/93, Sowing 3 on 20/12/93 and Sowing 4 on 12/4/94. LSD applies amongst accessions within an assessment date.

\begin{tabular}{|c|c|c|c|c|c|c|c|c|c|c|}
\hline \multirow{2}{*}{$\begin{array}{c}\text { Assessment } \\
\text { date }\end{array}$} & \multirow[t]{2}{*}{ Sowing } & \multicolumn{8}{|c|}{ Accession } & \multirow[b]{2}{*}{$\begin{array}{c}\text { LSD } \\
(\mathrm{P}<0.05)\end{array}$} \\
\hline & & $\begin{array}{c}C . \\
\text { ciliaris } \\
\text { Gayndah }\end{array}$ & $\begin{array}{c}U . \\
\text { mosambicensis } \\
\text { Nixon }\end{array}$ & $\begin{array}{c}U . \\
\text { oligotricha }\end{array}$ & $\begin{array}{c}U . \\
\text { stolonifera }\end{array}$ & $\begin{array}{c}\text { B. } \\
\text { bladhii }\end{array}$ & $\begin{array}{c}B . \\
\text { insculpta } \\
69517\end{array}$ & $\begin{array}{c}B . \\
\text { pertusa } \\
\text { Medway }\end{array}$ & $\begin{array}{c}P . \\
\text { stapfianum }\end{array}$ & \\
\hline \multirow[t]{2}{*}{$11 / 4 / 1994$} & 1 & 2.5 & 4.0 & 3.0 & 3.8 & 1.2 & 3.8 & 1.8 & 0.6 & 0.60 \\
\hline & 2 & 0.3 & 0.5 & 1.1 & 1.7 & 0.1 & 1.3 & 0.7 & 0.1 & 0.42 \\
\hline \multirow[t]{3}{*}{ 15/12/1994 } & 1 & 4.7 & 6.1 & 3.9 & 5.0 & 1.8 & 6.2 & 4.6 & 0.7 & 0.96 \\
\hline & 2 & 1.3 & 2.5 & 3.3 & 4.4 & 2.6 & 6.7 & 6.4 & 0.7 & 0.68 \\
\hline & 3 & 0.01 & 1.3 & 0.8 & 2.2 & 0.8 & 0.7 & 0.9 & 0.1 & 0.38 \\
\hline \multirow[t]{4}{*}{$24 / 2 / 1998$} & 1 & 3.7 & 8.9 & 2.6 & 2.9 & 1.3 & 8.9 & 3.0 & 0.9 & 0.83 \\
\hline & 2 & 4.0 & 8.6 & 1.7 & 2.8 & 2.6 & 8.8 & 2.9 & 1.4 & 1.08 \\
\hline & 3 & 0.1 & 8.9 & 3.0 & 3.7 & 5.9 & 7.9 & 3.4 & 0.7 & 1.19 \\
\hline & 4 & $0.2^{1}$ & 6.8 & 0.5 & 1.8 & 3.5 & 3.4 & 3.3 & 1.7 & 2.31 \\
\hline
\end{tabular}

${ }^{1}$ Gayndah replaced by C. ciliaris 73393 for this sowing. 
Table 5. Dry matter yield ratings of sown grasses near Roma on 3 occasions after the establishment phase. Ratings were on individual plots with the plot with the greatest yield (visually) of sown grass given 10, those lacking sown grass assigned zero, and a linear ranking applied for intermediate yields. Sowing 1 was on 23/11/93, Sowing 2 on 17/12/93 and Sowing 3 on 21/3/94. LSD applies amongst accessions within an assessment date.

\begin{tabular}{|c|c|c|c|c|c|c|c|c|c|c|}
\hline \multirow{2}{*}{$\begin{array}{c}\text { Assessment } \\
\text { date }\end{array}$} & \multirow[t]{2}{*}{ Sowing } & \multicolumn{8}{|c|}{ Accession } & \multirow[b]{2}{*}{$\begin{array}{c}\text { LSD } \\
(\mathrm{P}<0.05)\end{array}$} \\
\hline & & $\begin{array}{c}C . \\
\text { ciliaris } \\
\text { Gayndah }\end{array}$ & $\begin{array}{c}C . \\
\text { ciliaris } \\
71914\end{array}$ & $\begin{array}{c}P . \\
\text { stapfianum }\end{array}$ & $\begin{array}{c}B . \\
\text { pertusa } \\
\text { Medway }\end{array}$ & $\begin{array}{c}D . \\
\text { milanjiana }\end{array}$ & $\begin{array}{c}D . \\
\text { eriantha } \\
\text { Premier }\end{array}$ & $\begin{array}{c}E . \\
\text { curvula } \\
\text { Consol }\end{array}$ & $\begin{array}{c}E . \\
\text { curvula } \\
30374\end{array}$ & \\
\hline \multirow[t]{2}{*}{$6 / 4 / 1994$} & 1 & 1.0 & 2.9 & 0.2 & 1.0 & 2.6 & 0.9 & 0.5 & 1.3 & 0.38 \\
\hline & 2 & 2.2 & 3.6 & 0.4 & 1.8 & 3.4 & 1.4 & 1.1 & 1.9 & 0.46 \\
\hline \multirow[t]{2}{*}{$13 / 2 / 1995$} & 1 & 4.1 & 7.6 & 0.2 & 3.7 & 4.5 & 3.3 & 1.5 & 6.3 & 0.58 \\
\hline & 2 & 3.6 & 6.8 & 0.7 & 3.2 & 3.6 & 2.1 & 1.2 & 5.2 & 0.72 \\
\hline \multirow[t]{3}{*}{$5 / 6 / 1998$} & 1 & 6.6 & 8.7 & 0.9 & 6.7 & 5.7 & 4.9 & 3.0 & 7.5 & 1.15 \\
\hline & 2 & 7.2 & 8.2 & 0.4 & 8.0 & 6.0 & 4.4 & 4.3 & 6.7 & 1.04 \\
\hline & $3^{1}$ & 4.5 & 4.8 & 0.0 & 4.0 & 2.2 & 1.5 & 0.4 & 4.2 & 1.23 \\
\hline
\end{tabular}

${ }^{1}$ Only one replication with 3 treatment subplots (see Silcock and Finlay 2015) left after partial cultivation of the site.

The buffel grasses generally rated well as did Nixon sabi grass (U. mosambicensis), where it was tested (Tables 3 and 4). Conversely, B. ewartiana and P. stapfianum generally rated poorly for standing pasture yield. Ratings for these plants also remained relatively constant from 1994 to 1998 with $P$. stapfianum consistently low (Tables 4 and 5). The other accessions varied in their performance relative to Gayndah buffel (C. ciliaris).

At Condamine relative yield of $U$. stolonifera declined over time from excellent initial ratings for Sowings 1 and 2 (Table 4). Digitaria milanjiana followed a similar trend at the Roma site (Table 5), while Premier digit grass (D. eriantha) and Consol lovegrass (E. curvula) never performed better than buffel grass. In contrast E. curvula 30374 always had a good yield ranking at Roma (Table 5), partly because it was generally unpalatable once mature.

Although these perennial plants had the capacity to thicken up from a relatively poor seedling stand, as Bisset (B. insculpta) did at Yelarbon (Table 3) and B. insculpta 69517 at Condamine (Table 4), poor initial stands tended to remain sparse for many years. Thus no accessions in 1998 from Sowing 4 at Yelarbon (which had a low establishment success; Silcock and Finlay 2015) had ratings as good as those of the same accession from Sowing 3 (Table 3). Likewise, all sparse Sowing 3 stands at Roma rated worse in 1998 than those from Sowings 1 and 2 (Table 5), but such a pattern was not consistently evident at Condamine (Table 4). Any positive changes in yield ratings happened in the first or second year after sowing, after which declines in pasture yield over time were more common. Early improvers were Nixon sabi grass (U. mosambicensis) and Bisset bluegrass (B. insculpta) at Yelarbon (Table 3) and B. insculpta 69517 at Condamine (Table 4). Relative rankings of accessions tended to be consistent over time at Roma with the exception of D. milanjiana, which declined (Table 5).

\section{Seed production}

Seed was relatively easy to produce and harvest for both non-commercial Urochloa species and for E. curvula 30374. Seed of $U$. oligotricha is hairless so can be cleaned more readily than that of Nixon (U. mosambicensis) and $U$. stolonifera, while seed of E. curvula 30374 can be processed to almost pure caryopses if required, like cv. Consol. The non-commercial buffel grasses also produced good quantities of seed but C. ciliaris 73393 had to be sprayed after flowering to control the native seedhead-feeding grub, Mampava rhodoneura. Its dense seedhead, like that of cv. Biloela, made it more susceptible to attack compared with the more open seedhead of C. ciliaris 71914, which resembles cv. Gayndah.

Digitaria milanjiana flowered freely and produced seed of a quality similar to that of Premier digit grass (D. eriantha), without being infested with any insect pests or diseases. Likewise seed production problems in B. insculpta 52193 and B. insculpta 69517 bluegrass were similar to those normally experienced by the related commercial cultivars Hatch and Bisset. All have small, hairy seeds that ripen sequentially, do not flow readily when mechanically handled and are susceptible to ergot infection. Bothriochloa insculpta 52193 flowers slightly earlier than cv. Bisset, while B. insculpta 69517 
has noticeably higher seed yield, due to a larger seedhead and caryopsis.

Medway pertusa (B. pertusa), though similar to the creeping bluegrasses in growth habit and seedhead structure, was very prone to ergot attack at Gympie (D. Loch unpublished data). This reduced its seed yields and purity but had little effect on the viability of any harvested caryopses.

Bothriochloa bladhii CPI 11408, released soon after as cv. Swann forest bluegrass, had good seed production characteristics because it has a concentrated flowering period in summer and its seedheads are held clear of the main foliage. It was generally resistant to ergot attack and had a relatively high seed fill percentage for a bluegrass (Silcock and Finlay 2015). By comparison, it was difficult to harvest commercially useful quantities of seed from TN 47 desert bluegrass (B. ewartiana). Its seedlings developed few tillers in the sowing year and there were few seedheads $/ \mathrm{m}^{2}$ compared with all others except $P$. stapfianum. In addition, its seedheads were very susceptible to ergot attack, which reduced viable seed production further. Its seed yield in subsequent years improved as the stand thickened under fertilizer application and irrigation but invading grassy weeds resulted in extra costs and management problems.

Panicum stapfianum produced moderate seed yields and its heads drooped appreciably, so that catching the heads with a mechanical header required considerable skill. Sequential ripening of florets within a seedhead, typical of Panicum species, meant harvesting had to be done at either an optimal time, with a lot of potential seed lost, or several times with a brush harvester. However, the harvested seed, either direct-headed, swathed or hand-picked, was easy to clean, plump and flowed readily.

\section{Discussion}

This trial was the culmination of nearly 2 decades of research to select extra commercial pasture species for either ley farming systems or as replacements in the event of future serious pest outbreaks. The benchmark was existing commercial species selected chiefly for permanent, unfertilized perennial pastures. Ley farming is not yet widely practiced in Queensland and availability of fairly cheap seed is often a major factor determining what is sown.

The 11 non-commercial lines tested provided mixed success in meeting the objectives. The decline in productivity over time of many of the species tested was not unusual (Theron and Haylett 1953; Robbins et al. 1986; Dodd et al. 1990). Called pasture rundown, it was due primarily to a decline in available soil nitrogen, as nitrogen was tied-up in the robust perennial crowns of these tropical grasses (Meyers and Robbins 1991). Combating such rundown is the subject of much pasture research around the world (Peck et al. 2011), but perennial grasses are still the basis of long-term sustainable agricultural systems in subhumid and semi-arid environments.

\section{Accession summaries}

CPI 11408 B. bladhii var. glabra. This accession has since been released commercially as cv. Swann (PVJ 1996). Although this plant was imported as B. ischaemum from Guyana in 1948, it may be a native species because it is unlike that particular species. It may be a contaminant from nearby sown plots or from adjoining native southern Queensland pastures. No DNA testing has been done to investigate its possible origins. Commercial use of this cultivar is limited but it persists on some poorer soils that are unsuited to most other sown pasture grasses (DAFF 2014a). While seed yields are high $(>200 \mathrm{~kg} / \mathrm{ha})$, it produces only a single crop each year, in late summer. It has low palatability in winter but persists and provides roughage in dry seasons and winter, especially in lowly productive country. Postemergence atrazine at $2 \mathrm{~kg}$ a.i. (active ingredient)/ha had no effect on this plant.

TN $47 \mathrm{~B}$. ewartiana. This native grass had initial appeal in view of the strong lobby against exotic plants that may become weeds (Lonsdale 1994). While this plant can be grown commercially, seed is potentially very expensive, and it is not strongly competitive in the first growing season. Its major agronomic strengths are its persistence once established and a fairly broad soil adaptation. Established plants are resistant to atrazine, so seed-production plots can be sprayed to control summer annual grass weeds. It was tested towards the southern extremity of the natural distribution of the species at Yelarbon and may perform better further north.

CPI 52193 B. insculpta. This plant performed like $\mathrm{cv}$. Bisset, but with a slightly earlier flowering time. It presented some seed production problems in a coastal environment and seed quality was a little unpredictable. There is currently no requirement for it in competition with the existing small, struggling seed market for Hatch and Bisset creeping bluegrasses. It is susceptible to both pre- and post-emergence atrazine.

CPI 69517 B. insculpta. This strain of creeping bluegrass produces plenty of seed and performed as well 
as B. insculpta 52193 (Silcock et al. 2014). Ease of seed production is a major issue for tropical grasses (Hopkinson and English 1985; Hill and Loch 1993), so ease of establishment, good persistence and palatability under grazing of this plant could allow it to replace cv. Bisset. It outperformed buffel grass at Condamine and its production there matched that of Nixon sabi grass (U. mosambicensis). It is not as palatable to kangaroos as sabi grass and is not as well adapted to red earths (Silcock et al. 2014). Its relatively low palatability to stock unfamiliar with it, compared with Rhodes (Chloris gayana) and buffel grass, means farmers would tend to avoid it for short-term leys. Its most likely future role would be on hard-setting solodic soils, where it withstands trampling in wet times. Creeping bluegrass (B. insculpta) provides poorer ground cover than Medway pertusa ( $B$. pertusa) because the distance between rooted nodes is greater.

B. insculpta $c v$. Bisset. This plant has grown very well in the Maranoa region on a range of soil types (Lloyd et al. 2007). It is readily established from seed and persists well for many years. It is more easily plowed out than Medway pertusa (B. pertusa) and has not shown any tendency to spread into undisturbed native pasture. The prostrate dead litter and stubble results in lower densities of annual medics emerging in winter compared with adjacent buffel grass plots. Creeping bluegrasses (B. insculpta) are regarded as less nitrogen-demanding than many other grasses (DAFF 2014b), such as buffel and the panics.

B. pertusa $c v$. Medway. Medway pertusa has grown and persisted well and strains of this species are now regularly found along roadsides in the region. It is quite resistant to regular grazing and mowing and spreads easily over sparsely covered ground. While it does not have strong soil preferences, dry matter yields are quite low. Limited palatability makes its best role as a soil conservation grass. With its low tolerance of animal trampling, its use around yards and waterpoints is not recommended. Medway is not easily plowed out, but it is not as tolerant of plowing as tropical couch grasses (Cynodon spp.). Medway is susceptible to pre-emergence atrazine and mildly stunted by $2 \mathrm{~kg}$ a.i./ha once established. The Roma site was virtually devoid of it in 2006 following several lucerne crops sown with pre-emergent herbicide, combined with persistent dry years. The species is regarded as being moderately drought-tolerant but has persisted for decades in the absence of grazing at the Charleville airport and golf course (Bisset 1980). Medway is more leafy and productive than other strains of
B. pertusa (W. Scattini pers. comm.) but fails to maintain ground cover at critical times during droughts, like most other mat-forming perennial grasses adapted to this region.

CPI 71914 C. ciliaris. This accession has performed as well as cv. Gayndah in all ways and earned a slightly higher rating for dry matter yield at Roma. Its fluffy seed poses sowing problems and its sturdy crown would break down slowly after plowing out in a ley farming system. Like most buffel grasses (Loch and Harvey 1993), it is very sensitive to pre- and post-emergence atrazine herbicide. Like cv. Gayndah, its ability to colonize and spread naturally could pose problems adjacent to conservation reserves (Fairfax and Fensham 2000). It has persisted very well at several test sites on sandy, infertile red earths and is best suited as a permanent pasture. High costs of setting up a seed production program are not justified at this time, when so much seed of similar buffel grasses is available.

CPI 73393 C. ciliaris. This accession was planted on the best soil, the Yelarbon site, in an environment where cv. Biloela is the commonly sown buffel cultivar. It generally equalled or bettered Gayndah's production at this site but was no better than Biloela for this soil type. It is another germplasm that should be held in storage in case new pests or diseases arise that have to be overcome. No data exist on whether the leaf scorch disease, that can afflict several commercial strains of buffel grass (Cook et al. 2005a), is virulent on this line.

C. ciliaris $c v$. Gayndah. Gayndah buffel is the most common sown pasture grass in inland subtropical Australia, but is criticized in some circles for modifying the environment and altering fire regimes (Friedel et al. 2011). Years ago it was the savior of the Alice Springs environment by dramatically reducing dust levels after extensive planting (Puckey et al. 2004) and is highly regarded as a forage and cover by pastoralists worldwide. It has remained virtually pest- and disease-free in Australia for over 50 years but that cannot be guaranteed (Hall 2001). Hence alternatives with similar features, such as $C$. ciliaris 71914, should be available in the event that a devastating disease or pest emerges, as happened to American buffel in the USA and Mexico in 2000 (Cook et al. 2005a) and to Townsville stylo (Partridge 2003) and annual medics (Swann 1982) in Queensland in the past.

Gayndah buffel was easy to establish and grew very well at most sites, but performed quite poorly at Condamine and continues to thin out there. The reasons 
for this are not clear as Nixon sabi grass (U. mosambicensis) and B. insculpta 69517 both grew well there. This is an example of how certain soil types unexpectedly do not favor a climatically adapted plant and why there need to be comparable plants available to landholders. We did not sow C. ciliaris 71914 at this site so cannot comment on how it would have performed. There is negligible naturalized buffel grass along roads leading to the site, so the effect may be species-wide. Conversely, another Urochloa, liverseed grass (U. panicoides), is omnipresent at the Condamine site.

The severe loss of seed viability in our cold store was disappointing. The room was not de-humidified, and the Gayndah seed was in porous hessian sacks. Thus, the high humidity seems to have more than offset the low temperature in accelerating the deterioration of the buffel grass seed (Cameron 2003), along with that of several others (Silcock and Finlay 2015).

D. eriantha $c v$. Premier. This grass established and grew well at Roma where it was being compared with D. milanjiana. It was always palatable and would be a good short-term pasture with good spring season growth, if soil moisture existed. It was easily plowed out and replaced with lucerne. McDonald et al. (1998) consider it poses a problem on some sandy soils in southeast Queensland, where it persists under grazing and seems to tie up much of the available soil nitrogen without providing much forage, as buffel grass can sometimes do in the Maranoa and central Queensland highlands.

CPI 41192 D. milanjiana. This strain of D. milanjiana produces seed more readily than many related accessions (Hall and Walker 1994), is tolerant of moderately acid soils and will persist for many years in southwest Queensland (Silcock et al. 2014). It has better frost tolerance than other accessions such as CPI 59786 and cv. Jarra, which is important in southern inland Queensland. Seed production was not difficult and its seed cleaned up well in a cone thresher. It established well at Roma with reasonable follow-up rains and is fairly tolerant of atrazine once well established. Sward density was lower than that of Medway despite producing long stolons. Those stolons did not match the rooting tenacity of Medway pertusa (B. pertusa) or creeping bluegrass (B. insculpta) (Silcock et al. 2014).

This accession is very palatable and produced a good bulk of feed in the above-average summer of 1995/96. However, it was thinning out when the trial site was plowed out in early 2000 . Nonetheless, as a short-term ley pasture, it could fulfil a role on more acid mulga soils, where $D$. eriantha cv. Premier does not grow well.

CPI 30374 E. curvula. This chloromelas type (Gibbs Russell et al. 1990) establishes easily on infertile, acid soils (Filet 1988) and seed collection is very easy. It had seasonally poor palatability, especially when hayed-off, and produced masses of seedlings around parent plants. It was not grazed readily at Roma compared with cv. Consol but was far more productive and more easily established. It could not be considered for use further east than Roma because of the weed status of some naturalized strains of the species in traprock country and along roads in forestry regions. The plant was easily plowed and sprayed out from seed-production plots, and subsequent cultivation, along with cropping at the Roma site, has eliminated the plant there too.

Further west around Charleville, where it was extensively tested up to 1985 , it has failed to gain a foothold and died out readily during droughts. It persists only on sandy soils around Charleville township in the absence of grazing. No further testing of it is envisaged at this time but it is a benchmark against which to compare similar plants in future. Seed is maintained in the Australian Pastures Genebank (AusPGRIS 2014), along with the other accessions reported in this paper.

E. curvula var. conferta $c v$. Consol. Consol lovegrass did not persist and performed quite poorly, as it has at several other test sites (Silcock et al. 2014). It cannot be recommended for commercial use in southern Queensland and poses no weed threat where used, because it is palatable and non-competitive against native pastures.

CPI 73577 P. stapfianum. This panic has reaffirmed its status as being resistant to grazing and having low demands for soil fertility (Silcock et al. 2014). However, it was difficult to establish and slow to thicken-up thereafter. Seed yields were also very low, less than $25 \mathrm{~kg} / \mathrm{ha}$. Hence there is no case at present for its future commercial release. It has no weedy features and is very palatable when growing as small patches amongst other pastures, including to wildlife (kangaroos and rabbits). Established plants are very resistant to glyphosate.

U. mosambicensis $c v$. Nixon. Nixon has been in the market place for decades but has failed to gain popularity in southern Queensland. There may be several reasons for this - high palatability to kangaroos, low frost tolerance, plus poor palatability and dead leaf retention once hayed off. Around Roma is has been called 'acid grass' by some graziers, who say it is unpalatable to 
stock, especially once in seed. Many have concerns about it competing with buffel grass on fertile brigalow soils.

Nixon was easy to establish and grew as much bulk as any other grass sown. Neither site has been returned to cropping yet, so Nixon's persistence, after plowing and with possible use of pre-emergent herbicides, is unknown. It was less palatable than buffel in a timecontrolled grazing system at Yelarbon but was eaten and has not shown significant weedy features. It has persisted much better than anticipated. Its compatibility with annual medics is unclear, but it does not develop a thick litter mat like the creeping bluegrasses (B. insculpta), if lightly grazed. The mature crown is much less fibrous and persistent than those of buffel grasses.

CPI $47122 \mathrm{U}$. oligotricha. This accession displayed poor persistence but it was easy to produce commercial supplies of its large, non-hairy seed and to establish it. It had a longer leaf than Nixon (U. mosambicensis) and was very palatable, so is less likely to become weedy in the absence of regular grazing, e.g. along roadsides. It is not very susceptible to the pre-emergence herbicide atrazine, so special management may be needed to remove it from cultivated situations. Its appreciable level of seed dormancy may pose a weed problem, similar to that of liverseed grass.

CPI 60128 U. stolonifera. This grass showed general promise and stands thickened easily from its moderately long stolons. It is very like Nixon - susceptible to frost, unpalatable in winter, has hairy seed, while high seed yields over $200 \mathrm{~kg} / \mathrm{ha}$ are easily achieved. A tendency towards red coloration on the leaves under stress is a distinguishing trait. It is susceptible to the same herbicides as Nixon (Cook et al. 2005b) and very tolerant of $2 \mathrm{~kg}$ a.i./ha of atrazine once established.

It has since been released as cv. Saraji for minesite rehabilitation purposes (PVJ 1997). Thus it is like many pasture grasses that are used for their environmental values, but is the only one in Australia not released primarily as a forage plant. It establishes easily and grows well on acid soils. There seems no extra role for it in forage systems, while cv. Nixon is available.

\section{Conclusions}

Several experimental accessions of perennial grass proved to be as agronomically valuable as the current limited list available for sown pastures in subhumid, southern inland Queensland. Table 6 summarizes the performance of the tested accessions for both short- (1-3 years) and long-term (15 years or more) roles under local property grazing management. Some are potential alternatives should commercial types succumb to a new pest or disease, provided that they too are not susceptible. None was sufficiently superior to justify starting commercial seed production at present, especially as seed production of bluegrasses ( $B$. insculpta) is difficult due to ergot susceptibility of the inflorescence in moister environments, where the seed production industry is based.

Table 6. Summary of the relative performance and persistence as pasture biomass of the accessions tested. Note: not all accessions were sown at each site, because prior testing had identified those most likely to grow and persist well.

\begin{tabular}{|c|c|c|c|c|c|c|}
\hline \multirow{2}{*}{$\begin{array}{l}\text { Trial site: } \\
\text { Soil attributes: } \\
\text { Time period: }\end{array}$} & \multicolumn{2}{|c|}{$\begin{array}{l}\text { Yelarbon } \\
\text { grey sandy medium cracking clay }\end{array}$} & \multicolumn{2}{|c|}{$\begin{array}{l}\text { Condamine } \\
\text { firm brown gritty loam over } \\
\text { mottled clay }\end{array}$} & \multicolumn{2}{|c|}{$\begin{array}{l}\text { Roma } \\
\text { hard-setting red sandy loam over } \\
\text { brown clay }\end{array}$} \\
\hline & Short-term & Long-term & Short-term & Long-term & Short-term & Long-term $^{1}$ \\
\hline Best performing & $\begin{array}{l}\text { C. ciliaris } \\
73393 \text {, } \\
\text { Nixon }\end{array}$ & $\begin{array}{l}\text { Bisset, } \\
\text { Nixon }\end{array}$ & Nixon & $\begin{array}{l}\text { Nixon, } \\
\text { B. insculpta } \\
69517\end{array}$ & $\begin{array}{l}\text { C. ciliaris } \\
71914, \\
\text { D. milanjiana }\end{array}$ & C. ciliaris 71914 \\
\hline Performed well & $\begin{array}{l}\text { U. oligotricha, } \\
\text { Bisset }\end{array}$ & $\begin{array}{l}\text { Gayndah, } \\
\text { B. insculpta } \\
52193\end{array}$ & $\begin{array}{l}\text { Gayndah, } \\
\text { U. stolonifera }\end{array}$ & $\begin{array}{l}\text { Medway, } \\
\text { B. bladhii }\end{array}$ & $\begin{array}{l}\text { E. curvula } \\
30374, \\
\text { Gayndah, } \\
\text { Medway }\end{array}$ & $\begin{array}{l}\text { Medway, } \\
\text { Gayndah, } \\
\text { E. curvula } \\
30374\end{array}$ \\
\hline Worst performing & $\begin{array}{l}\text { B. ewartiana, } \\
\text { B. bladhii }\end{array}$ & U. oligotricha & P. stapfianum & $\begin{array}{l}\text { Gayndah, } \\
\text { U. oligotricha, } \\
P . \text { stapfianum }\end{array}$ & $\begin{array}{l}\text { P. stapfianum, } \\
\text { Consol }\end{array}$ & P. stapfianum \\
\hline
\end{tabular}

${ }^{1}$ Not well assessed here because plowed out several times and oversown with lucerne. Assessment based on surviving plants in the surrounding headlands. 
The very palatable $U$. oligotricha seems suited for short-term pastures, if sufficient demand arises in future. By contrast, despite being native and environmentally well adapted, B. ewartiana TN 47 is not agronomically suited for a ley pasture role in this region.

\section{Acknowledgments}

We thank Dr. John Hopkinson and his staff at Walkamin for producing some of the seed for these trials. Ms. Janet Giles and Ms. Alison Kelly assisted with the statistical analyses. We are extremely grateful to the property owners for the use of their land and their help with sowing operations.

\section{References}

AusPGRIS. 2014. Australian Plant Genetic Resources Information System. www2.dpi.qld.gov.au/extra/asp/auspgris/

Bellotti WD; Bowman A; Silcock RG. 1991. Sown pastures for marginal cropping lands in the subtropics. Tropical Grasslands 25:197-204.

Bisset WJ. 1980. Indian bluegrass has special uses. Queensland Agricultural Journal 106:507-517.

Blacket D. 1992. Selecting suitable pastures. In: Lawrence D; French V, eds. Sown pasture management notes: Western Downs \& Maranoa. Queensland Department of Primary Industries SQA 92002, Brisbane, Australia. p. 19-36.

Cameron AG. 2003. Seed storage in the NT tropics. Agnote C35, Northern Territory Department of Primary Industry, Fisheries and Mines, Darwin, NT, Australia. www.nt. gov.au/d/Content/File/p/Crop/785.pdf

Cook BG; Pengelly BC; Brown SD; Donnelly JL; Eagles DA; Franco MA; Hanson J; Mullen BF; Partridge IJ; Peters M; Schultze-Kraft R. 2005a. Cenchrus ciliaris. In: Tropical Forages: An interactive selection tool. [CD-ROM], CSIRO, DPI\&F(Qld), CIAT and ILRI, Brisbane, Australia. http://goo.gl/L1Y1uH

Cook BG; Pengelly BC; Brown SD; Donnelly JL; Eagles DA; Franco MA; Hanson J; Mullen BF; Partridge IJ; Peters M; Schultze-Kraft R. 2005b. Urochloa mosambicensis. In: Tropical Forages: An interactive selection tool. [CDROM], CSIRO, DPI\&F(Qld), CIAT and ILRI, Brisbane, Australia. http://goo.gl/nTGI5H

DAFF. 2014a. Pastures for the traprock, sandstone and dry granite country - south-east Downs. Queensland Department of Agriculture, Fisheries and Forestry, Brisbane, Australia. http://goo.gl/XEYkaD

DAFF. 2014b. Creeping bluegrass. Queensland Department of Agriculture, Fisheries and Forestry, Brisbane, Australia. http://goo.gl/k7Sg9Y

Dodd MB; Chu ACP; Matthews PNP. 1990. Can we reverse the process of deterioration in a run down prairie grass pasture? Proceedings of the New Zealand Grassland Association 51:123-126.
Fairfax RJ; Fensham RJ. 2000. The effect of exotic pasture development on floristic diversity in central Queensland, Australia. Biological Conservation 94:11-21. DOI: 10.1016/s0006-3207(99)00169-x

Filet PG. 1988. Evaluation of animal performance and pasture persistence under continuous stocking of sown pastures on sandy mulga soils (W.R.D.F. DAQ08P). Report on Terminated Project, Queensland Department of Primary Industries, Charleville Pastoral Laboratory, Charleville, Qld, Australia. http://goo.gl/E6Htk0

Friedel MH; Grice AC; Marshall NA; van Klinken RD. 2011. Reducing contention amongst organisations dealing with commercially valuable but invasive plants: The case of buffel grass. Environmental Science \& Policy 14:12051218. DOI: $10.1016 /$ j.envsci.2011.08.001

GENSTAT. 1987. GenStat 5 release 1, reference summary. Lawes Agricultural Trust, Rothamsted Experimental Station, Harpenden, UK.

Gibbs Russell GE; Watson L; Koekemoer M; Smook L; Barker NP; Henderson HM; Dallwitz MJ. 1990. Grasses of Southern Africa. Memoirs of the Botanical Survey of South Africa No. 58. National Botanic Gardens/Botanical Research Institute, Pretoria, South Africa. p. 148.

Hall TJ. 2001. History and development of buffel grass pasture lands in Queensland. In: Cook B, ed. Buffel Grass Symposium: Proceedings of workshop held at Theodore, Qld, on 21-23 February 2000. QC00010. Queensland Department of Primary Industries, Brisbane, Australia. p. 2-12. DOI: $10.1071 /$ ea9940355

Hall TJ; Walker RW. 1994. Selection of perennial grasses as a component of legume-based pastures on light-textured soils in the dry tropics of Queensland. Australian Journal of Experimental Agriculture 34:355-365.

Hill MJ; Loch DS. 1993. Achieving potential herbage seed yields in tropical regions. In: Baker MJ, ed. Grasslands for our World. SIR Publishing, Wellington, New Zealand. p. 652-658.

Hopkinson JM; English BH. 1985. Immaturity as a cause of low quality in seed of Panicum maximum. Journal of Applied Seed Production 3:24-27.

Lloyd D; Johnson B; O'Brien S. 2007. Sown pasture grasses and legumes for marginal cropping lands in southern inland Queensland. Tropical Grasslands 41:164-173.

Loch DS; Harvey GL. 1993. Preliminary screening of 17 tropical grasses for their tolerance to eight graminaceous herbicides. Proceedings of the XVII International Grassland Congress, New Zealand and Australia, 1993. p. 1646-1648.

Lonsdale WM. 1994. Inviting trouble: Introduced pasture weeds in northern Australia. Australian Journal of Ecology 19:345-354. DOI: $10.1111 /$ j.1442-9993.1994.tb00 498.x

McDonald CK; Jones RM; Tothill JC. 1998. Growth and spread of Digitaria eriantha cv. Premier and Urochloa mosambicensis cv. Nixon oversown into native speargrass (Heteropogon contortus) pasture in south-east Queensland. Tropical Grasslands 32:41-49. 
Myers RJK; Robbins GB. 1991. Sustaining productive pastures in the tropics. 5. Maintaining productive sown pastures. Tropical Grasslands 25:104-110.

Partridge I. 2003. Townsville stylo (Stylosanthes humilis). In: Humphreys LR; Partridge IJ, eds. Better pastures for the tropics and subtropics. http://goo.gl/2QJWN2

Peck GA; Buck SR; Hoffman A; Holloway C; Johnson B; Lawrence DN; Paton CJ. 2011. Review of productivity decline in sown grass pastures. Meat and Livestock Australia, North Sydney, NSW, Australia. http://goo.gl/ 2yaF9h.

Puckey H; O'Malley C; Waycott M; Friedel MH. 2004. The dispersal, impact and management of buffel grass (Cenchrus ciliaris) in central Australia. In: Bastin GN; Walsh D; Nicolson S, eds. Living in the Outback: Proceedings of the 13th Biennial Conference, Australian Rangeland Society, Alice Springs, Northern Territory, Australia, 5-8 July 2004. p. 347-348.

PVJ. 1996. Forest Blue Grass 'Swann'. Plant Varieties Journal 9(4):29.

PVJ. 1997. Urochloa 'Saraji'. Plant Varieties Journal 10(2):55.

Rainman. 2003. Rainman - StreamFlow version 4.3: A comprehensive climate and streamflow analysis package on $\mathrm{CD}$ to assess seasonal forecasts and manage climate risk.
QI03040. Queensland Department of Primary Industries, Brisbane, Australia.

Robbins GB; Rickert KG; Humphreys LR. 1986. Productivity decline in sown tropical grass pasture with age: The problem and possible solutions. Proceedings of the Australian Society of Animal Production 16:319-322.

Silcock RG; Finlay CH. 2015. Perennial pastures for marginal farming country in southern Queensland. 1. Grass establishment techniques. Tropical Grasslands-Forrajes Tropicales, this volume.

Silcock RG; Hilder TJ; Finlay CH. 2014. Evaluating pasture species for less fertile soils in a subtropical aseasonal low rainfall zone. Tropical Grasslands-Forrajes Tropicales 2:223-245.

Swann IF. 1982. Pastures on the traprock, sandstone and dry granite lands of the Warwick district. Queensland Agricultural Journal 108:50-56.

Theron JJ; Haylett DG. 1953. The regeneration of soil humus under a grass ley. Empire Journal of Experimental Agriculture 21:86-98.

Thompson P. 1988. Improving livestock profitability with pasture and forage crops - pasture and forage guidelines for the Darling Downs, Western Downs and Maranoa. Bowdler, English and Wehl Seed and Grain and Annand, Robinson and Co., Toowoomba, Qld, Australia.

(Received for publication 6 June 2014; accepted 20 December 2014)

Tropical Grasslands-Forrajes Tropicales is an open-access journal published by Centro Internacional de Agricultura Tropical (CIAT). This work is licensed under a Creative Commons Attribution-NonCommercial-ShareAlike 3.0 Unported License. To view a copy of this license, visit http://creativecommons.org/licenses/by-nc-sa/3.0/ 